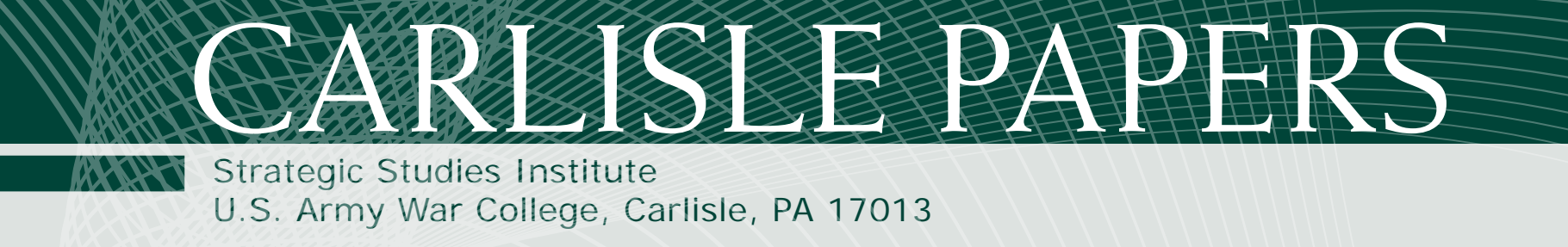

\title{
Government Contracting Should be a Core Competence for U.S. Military Personnel
}

LTC Katherine E. White, USAR

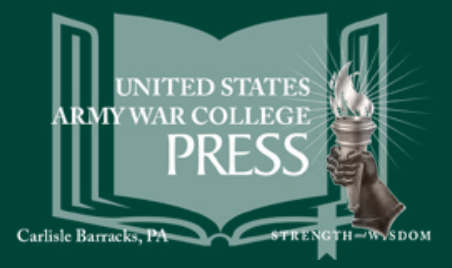




\section{Report Documentation Page}

Form Approved

OMB No. 0704-0188

Public reporting burden for the collection of information is estimated to average 1 hour per response, including the time for reviewing instructions, searching existing data sources, gathering and maintaining the data needed, and completing and reviewing the collection of information. Send comments regarding this burden estimate or any other aspect of this collection of information,

including suggestions for reducing this burden, to Washington Headquarters Services, Directorate for Information Operations and Reports, 1215 Jefferson Davis Highway, Suite 1204, Arlington

VA 22202-4302. Respondents should be aware that notwithstanding any other provision of law, no person shall be subject to a penalty for failing to comply with a collection of information if it

does not display a currently valid OMB control number.

\begin{tabular}{|c|c|}
\hline $\begin{array}{l}\text { 1. REPORT DATE } \\
\text { DEC } \mathbf{2 0 1 4}\end{array}$ & $\begin{array}{l}\text { 3. DATES COVERED } \\
\mathbf{0 0 - 0 0 - 2 0 1 4} \text { to 00-00-2014 }\end{array}$ \\
\hline \multirow{3}{*}{$\begin{array}{l}\text { Government Contracting Should Be a Core Competence for U.S. Military } \\
\text { Personnel }\end{array}$} & 5a. CONTRACT NUMBER \\
\hline & 5b. GRANT NUMBER \\
\hline & 5c. PROGRAM ELEMENT NUMBER \\
\hline \multirow[t]{3}{*}{ 6. AUTHOR(S) } & 5d. PROJECT NUMBER \\
\hline & 5e. TASK NUMBER \\
\hline & 5f. WORK UNIT NUMBER \\
\hline $\begin{array}{l}\text { 7. PERFORMING ORGANIZATION NAME(S) AND ADDRESS(ES) } \\
\text { U.S. Army War College,Strategic Studies Institute,Carlisle } \\
\text { Barracks,PA,17013 }\end{array}$ & $\begin{array}{l}\text { 8. PERFORMING ORGANIZATION } \\
\text { REPORT NUMBER }\end{array}$ \\
\hline \multirow[t]{2}{*}{ 9. SPONSORING/MONITORING AGENCY NAME(S) AND ADDRESS(ES) } & 10. SPONSOR/MONITOR'S ACRONYM(S) \\
\hline & $\begin{array}{l}\text { 11. SPONSOR/MONITOR'S REPORT } \\
\text { NUMBER(S) }\end{array}$ \\
\hline
\end{tabular}

12. DISTRIBUTION/AVAILABILITY STATEMENT

Approved for public release; distribution unlimited

13. SUPPLEMENTARY NOTES

14. ABSTRACT

15. SUBJECT TERMS

16. SECURITY CLASSIFICATION OF:

\begin{tabular}{c|c|c|c|}
$\begin{array}{c}\text { a. REPORT } \\
\text { unclassified }\end{array}$ & $\begin{array}{c}\text { b. ABSTRACT } \\
\text { unclassified }\end{array}$ & $\begin{array}{c}\text { c. THIS PAGE } \\
\text { unclassified }\end{array}$ & $\begin{array}{c}\text { Same as } \\
\text { Report (SAR) }\end{array}$
\end{tabular}

\begin{tabular}{c|l}
$\begin{array}{c}\text { 18. NUMBER } \\
\text { OF PAGES } \\
\mathbf{3 3}\end{array}$ & 19a. NAME OF \\
& RESPONSIBLE PERSON \\
&
\end{tabular}




\section{The United States Army War College}

The United States Army War College educates and develops leaders for service at the strategic level while advancing knowledge in the global application of Landpower.

The purpose of the United States Army War College is to produce graduates who are skilled critical thinkers and complex problem solvers. Concurrently, it is our duty to the U.S. Army to also act as a "think factory" for commanders and civilian leaders at the strategic level worldwide and routinely engage in discourse and debate concerning the role of ground forces in achieving national security objectives.
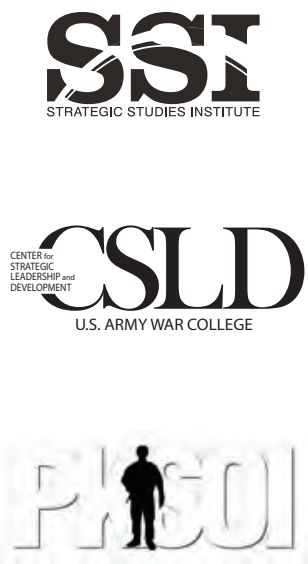

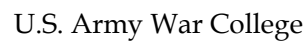
SLDR

Senior Leader Development and Resiliency
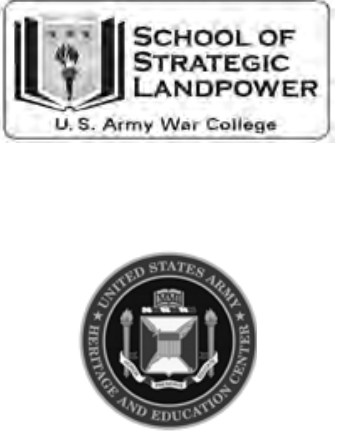

The Strategic Studies Institute publishes national security and strategic research and analysis to influence policy debate and bridge the gap between military and academia.

The Center for Strategic Leadership and Development contributes to the education of world class senior leaders, develops expert knowledge, and provides solutions to strategic Army issues affecting the national security community.

The Peacekeeping and Stability Operations Institute provides subject matter expertise, technical review, and writing expertise to agencies that develop stability operations concepts and doctrines.

The Senior Leader Development and Resiliency program supports the United States Army War College's lines of effort to educate strategic leaders and provide well-being education and support by developing self-awareness through leader feedback and leader resiliency.

The School of Strategic Landpower develops strategic leaders by providing a strong foundation of wisdom grounded in mastery of the profession of arms, and by serving as a crucible for educating future leaders in the analysis, evaluation, and refinement of professional expertise in war, strategy, operations, national security, resource management, and responsible command.

The U.S. Army Heritage and Education Center acquires, conserves, and exhibits historical materials for use to support the U.S. Army, educate an international audience, and honor Soldiers - past and present. 


\section{STRATEGIC STUDIES INSTITUTE}

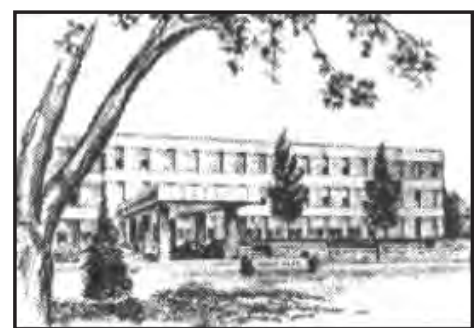

The Strategic Studies Institute (SSI) is part of the U.S. Army War College and is the strategic-level study agent for issues related to national security and military strategy with emphasis on geostrategic analysis.

The mission of SSI is to use independent analysis to conduct strategic studies that develop policy recommendations on:

- Strategy, planning, and policy for joint and combined employment of military forces;

- Regional strategic appraisals;

- The nature of land warfare;

- Matters affecting the Army's future;

- The concepts, philosophy, and theory of strategy; and,

- Other issues of importance to the leadership of the Army.

Studies produced by civilian and military analysts concern topics having strategic implications for the Army, the Department of Defense, and the larger national security community.

In addition to its studies, SSI publishes special reports on topics of special or immediate interest. These include edited proceedings of conferences and topically oriented roundtables, expanded trip reports, and quick-reaction responses to senior Army leaders.

The Institute provides a valuable analytical capability within the Army to address strategic and other issues in support of Army participation in national security policy formulation. 



\author{
Strategic Studies Institute \\ and \\ U.S. Army War College Press
}

\title{
GOVERNMENT CONTRACTING SHOULD BE A CORE COMPETENCE FOR U.S. MILITARY PERSONNEL
}

\section{Lieutenant Colonel Katherine E. White, USAR}

\section{December 2014}

The views expressed in this report are those of the author and do not necessarily reflect the official policy or position of the Department of the Army, the Department of Defense, or the U.S. Government. Authors of Strategic Studies Institute (SSI) and U.S. Army War College (USAWC) Press publications enjoy full academic freedom, provided they do not disclose classified information, jeopardize operations security, or misrepresent official U.S. policy. Such academic freedom empowers them to offer new and sometimes controversial perspectives in the interest of furthering debate on key issues. This report is cleared for public release; distribution is unlimited.

This publication is subject to Title 17, United States Code, Sections 101 and 105. It is in the public domain and may not be copyrighted. 


\begin{abstract}
$* * * * *$
Comments pertaining to this report are invited and should be forwarded to: Director, Strategic Studies Institute and U.S. Army War College Press, U.S. Army War College, 47 Ashburn Drive, Carlisle, PA 17013-5010.

All Strategic Studies Institute (SSI) and U.S. Army War College (USAWC) Press publications may be downloaded free of charge from the SSI website. Hard copies of this report may also be obtained free of charge while supplies last by placing an order on the SSI website. SSI publications may be quoted or reprinted in part or in full with permission and appropriate credit given to the U.S. Army Strategic Studies Institute and U.S. Army War College Press, U.S. Army War College, Carlisle, PA. Contact SSI by visiting our website at the following address: www.StrategicStudiesInstitute.army.mil.
\end{abstract}

The Strategic Studies Institute and U.S. Army War College Press publishes a monthly email newsletter to update the national security community on the research of our analysts, recent and forthcoming publications, and upcoming conferences sponsored by the Institute. Each newsletter also provides a strategic commentary by one of our research analysts. If you are interested in receiving this newsletter, please subscribe on the SSI website at www.StrategicStudiesInstitute.army.mil/newsletter.

ISBN 1-58487-655-7 


\section{PREFACE}

The U.S. Army War College (USAWC) provides an excellent environment for selected military officers and government civilians to reflect and capitalize on their career experience to explore a wide range of strategic issues. To ensure that the research conducted by USAWC students is available to Army and Department of Defense leaders, the Strategic Studies Institute publishes selected papers in its "Carlisle Papers" series.

\section{STEVEN METZ}

Director of Research

Strategic Studies Institute 



\begin{abstract}
ABOUT THE AUTHOR
KATHERINE E. WHITE is a Professor of Law at Wayne State University in Detroit, MI, where she has taught for 18 years, specializing in patent law and contracts. Professor White continues to serve as a Lieutenant Colonel in the U.S. Army Reserves. She has taught as a reservist at the U.S. Army Judge Advocate General's Legal Center and School (JAG School) in the Contract and Fiscal Law Department. She has also served as the Associate Dean for the JAG School. Most recently, she taught military and constitutional law to First Class Cadets at the United States Military Academy at West Point, NY. While on active duty, she served as the Intellectual Property Counsel for the U.S. Army Corps of Engineers, where she was a member of the Office of the Chief Counsel's Honors Program. After leaving active duty, Professor White was a judicial law clerk to the Honorable Randall R. Rader, Circuit Judge (Ret.), U.S. Court of Appeals for the Federal Circuit. Elected statewide in Michigan in 1998 and re-elected in 2006 and 2014, Professor White currently serves as the Chair of the University of Michigan Board of Regents. In addition, she is a Fulbright Senior Scholar, a White House Fellow (2001-02), and a registered patent attorney. Professor White holds a B.S.E. degree in electrical engineering and computer science from Princeton University, a J.D. degree from the University of Washington, a LL.M. degree in intellectual property law from the George Washington University Law School, and a master's degree in strategic studies from the U.S. Army War College.
\end{abstract}





\section{SUMMARY}

The Wars in Iraq and Afghanistan mark an era of unprecedented outsourcing in contingency operations. Although significant outsourcing occurred in prior wars, never has the scale been so large for so long. Counterintuitively, as outsourcing increased, the number of government acquisition personnel decreased. This led to waste, fraud, and abuse. The Commission on Wartime Contracting made several findings and recommendations to prevent future contract administration problems in contingency operations. A principal concern is that the U.S. military needs to increase the number of acquisition experts, change its culture, and treat government contracting as a core competency.

In response to outsourcing concerns, the Office of Federal Procurement Policy issued Policy Letter 11-01 on the Performance of Inherently Governmental and Critical Functions. The Letter provides strategic-level guidance to federal agencies to assess risk and accountability when outsourcing. Although the Letter provides helpful guidance, it is only a first step. More is needed to prevent the contract administration failures of the wars in Iraq and Afghanistan from recurring. This Paper examines further-needed steps and ways in which the U.S. military can change its culture and make government contracting a core competency. 



\section{GOVERNMENT CONTRACTING SHOULD BE A CORE COMPETENCE FOR U.S. MILITARY PERSONNEL}

During Operation IRAQI FREEDOM (OIF) and Operation ENDURING FREEDOM $(\mathrm{OEF})$, civilian contractors comprised over half of the U.S. presence in Iraq and Afghanistan. ${ }^{1}$ In fact, there were more "private military contactors on the ground in [OIF] than troops from any one ally, including Britain." ${ }^{2}$ Without sufficient personnel with acquisition management expertise to deploy in theater, oversight was deficient; this led to significant waste, fraud, and abuse in government contracting. To address these concerns, Congress created the Commission on Wartime Contracting (Commission) to study the acquisition processes in OIF and OEF. ${ }^{3}$ In 2011, the Commission's Final Report (Final Report) published its findings and recommendations. Concomitantly, the Office of Federal Procurement Policy (OFPP) issued Policy Letter 11-01 (Letter) on the Performance of Inherently Governmental and Critical Functions. ${ }^{4}$ The Letter's purpose is to provide strategic-level guidance to federal agencies to assess risk and accountability when outsourcing critical functions and closely related, inherently governmental functions. The Letter is beneficial, but is merely a first step in addressing the procurement problems the Commission identified in OIF/OEF.

Specifically, instead of principally looking at cost considerations when deciding whether to outsource, the Commission recommends a risk-based approach, in which risk factors are used to weigh contracting decisions. ${ }^{5}$ Some functions may create undue risk and thus should not be contracted out, regardless of whether outsourcing reduces costs. The Letter, in its original form, included a type of risk-based approach, ${ }^{6}$ but that language was unfortunately dropped in the Letter's final version.

Although the Letter addresses some concerns expressed in the Report, other important findings and recommendations the Commission made are unlikely to become part of the U.S. Army's ethos unless more action is taken beyond the Letter. Both the Letter and the Commission recognize the significant need for additional acquisition personnel to manage contract administration in contingency operations. But, to increase such personnel, congressional funding is required, and agencies cannot address this problem on their own.

Although there is widespread agreement that federal agencies need to substantially increase acquisition management personnel to handle contract administration and oversight, ${ }^{7}$ there is less focus on the need to change the culture so contracting truly becomes a core competency. The Commission found that federal agencies treat contracting as a supporting function and "have not institutionalized acquisition as a core function." ${ }^{8} \mathrm{~A}$ major recommendation is that a new contracting directorate, J10, should be created as a Joint Staff function to ensure that contingency contracting is coordinated across agencies, provide contractor support in planning and preparation, foster cost efficiency, and proactively identify acquisition issues and challenges at the highest leadership level. ${ }^{9}$ Currently, contracting is incorporated as a subordinate role within the Joint Staff's logistics directorate (J4).

Although there are efforts to increase the number of General/Flag Officers responsible for acquisition management, there has not yet been a move to create a contracting directorate. ${ }^{10}$ Such an elevation would signal that acquisition is no longer just a 
support function, but is core and central to an agency's mission and would institutionalize contract support, thereby communicating across and through Services and unified commands. ${ }^{11}$ This elevation would be more likely to change the culture than keeping the contracting role buried within the J4 directorate. Without changing Army culture to make contracting a core competency, the procurement mistakes made in OIF/OEF are likely to recur in future contingency operations. Plus, having a contracting directorate would increase the likelihood of interagency coordination in procurement and acquisition management.

\section{HISTORY}

\section{What Happened to Create the Outsourcing Crisis in OIF and OEF?}

Over decades, both Democratic and Republican presidential administrations have made political decisions to "shrink" the size of the Federal Government (Government). ${ }^{12}$ Throughout this time, however, the work of the Government has not actually decreased. Thus, any functions federal employees do not perform must be outsourced to contractors. ${ }^{13}$ For example, between 1990 and 2002, approximately 727,000 contractor jobs were created to support the Government's work. ${ }^{14}$ Since then, Government mandates have continued to increase. Thus, to keep up, agencies have had only one choice - "[to] rely upon contractors to perform mission-critical services," 15 that civil servants traditionally performed, like acquisition program management, policy analysis, and quality assurance. ${ }^{16}$ Paul Light has referred to this as the "true size" of Government, which is "the total workforce required to deliver the promises the Federal Government has made," including contractor personnel. ${ }^{17}$ These numbers are difficult to estimate, because federal agencies do not keep precise data on how many people "earn their living or spend their time producing goods and services through federal contracts, grants, or mandates. These are not the kind of data the government likes to keep, especially in an era of public anger and frustration toward big [G]overnment."18

To keep up with the increased workload, the Government uses personal service contracting to augment shortfalls with federal employee personnel. Personal service contracting is a mechanism whereby the Government retains the function, but the contractor employees staff the effort. ${ }^{19}$ A problem arose as to how government employees were supposed to work alongside contractor employees. Contractors were not trained to replace Government personnel, and Government personnel were not trained in how to supervise contractors. ${ }^{20}$ Because personal service contracts empower the contractor to make discretionary decisions previously reserved by, or legally required to be made, by officials, these types of contracts became fodder for significant criticism. ${ }^{21}$ Unfortunately, to add to the problem, Congress created the perfect storm. Just as contractors performed more critical functions for federal agencies, Congress cut the federal employee acquisition workforce numbers. ${ }^{22}$

The Fay Report, ${ }^{23}$ which documents significant contractor oversight problems that took place in Abu Ghraib prison in Baghdad, Iraq, identifies personal service contracting as one reason things went awry. There was no protocol about "the appropriate relationship between contractor personnel, government civilian employees, and military person- 
nel. . . . [C]ontractor personnel were 'supervising' government personnel or vice versa." 24 Initially, the response was to hire more auditors and create more Inspector General positions. In other words, the most significant initial response was to address enforcement rather than focus on preventing the problem. Both the Letter and the Commission have identified that more emphasis is needed on hiring more acquisition personnel to prevent contract administration abuses. ${ }^{25}$

Without proper acquisition personnel oversight, contractors have been allowed to act like government employee contracting officers and draft statements of work, as well as to develop, issue, and administer contracts. ${ }^{26}$ Allowing contractors to perform such functions circumvents the Government's public function to provide accountability for these decisions. ${ }^{27}$ Without proper oversight and accountability, the acquisition process loses its integrity, especially when contractors have a conflict of interest in administering the contracts they perform. ${ }^{28}$

Both the Commission's findings and recommendations and the Letter's guidance note the need for federal employee acquisition personnel numbers to increase significantly. To do this, however, Congress must provide adequate funding so the shortcomings of the past can be remedied. Increased federal funding for hiring more acquisition experts is the only option to address contract administration problems. There is generally no desire to increase the size of federal employment enough to reverse the outsourcing trend. Even if there were, however, it would still be unlikely the Government could obtain a sufficiently talented workforce to do all the Government's work, because the private sector, through higher salaries, lures away the best talent. ${ }^{29}$

\section{OVERVIEW}

\section{Commission on Wartime Contracting Findings and Recommendations.}

As part of the National Defense Authorization Act for Fiscal Year 2008, Congress created the independent, bipartisan legislative Commission to study contracting in Iraq during OIF and in Afghanistan during OEF. ${ }^{30}$ In August 2011, the Commission submitted the Report to Congress and made findings and recommendations regarding the extent of waste, fraud, and abuse contracting problems in OIF/OEF. ${ }^{31}$ Between $\$ 31$ to $\$ 60$ billion has been lost to waste and abuse in OIF/OEF contracting, and more is likely to have been lost after the Report was submitted. ${ }^{32}$ The findings with commensurate recommendations are included in the following pages.

\section{"Agencies Overly Rely on Contractors for Contingency Operations." 33}

Because agencies lack the organic capacity to carry out many mission-critical functions, agencies over-rely on contractors in contingency operations. Such shortages of Government personnel are in part due to statutory and budgetary limits on the number of military personnel and federal employees. Other contingency operations did not create the same problems, because the contracting levels during OIF/OEF are unprecedented and have lasted over a long period of time. ${ }^{34}$ There was little preparation to manage the number of contractors and the scope of their work. ${ }^{35}$ Further, contractors 
often perform activities that are supposed to be reserved only for government personnel. ${ }^{36}$ Consequently, the Government lacks enough acquisition personnel to administer and manage those contracts effectively; this has led to widespread waste, fraud, and abuse. Such over-reliance on contractors erodes institutional knowledge and agency core capabilities, which leads to the need to hire more contractors to make up for capability deficits. ${ }^{37}$ To further complicate matters, contractors have been killed and injured in high numbers that are not adequately accounted for, unlike military casualties, which hides the real cost of war. ${ }^{38}$

Importantly, for a decade, contingency operations funding has skirted the regular budgetary process; it has instead been labeled "emergency spending" and funded through supplemental appropriations. ${ }^{39}$ This has the result of hiding the true cost of OIF/OEF, which enables agencies to avoid making tough decisions to prioritize and make strategic cuts to their overall budgets. ${ }^{40}$

\section{“'Inherently Governmental' Rules Do Not Guide Appropriate Use of Contractors in Contingencies." 41}

\section{Recommendations:}

- "Use risk factors in deciding whether to contract in contingencies." 42

- "Develop deployable cadres for acquisition management and contractor oversight." 43

- "Phase out use of private security contracts for certain functions." 44

- "Improve interagency coordination and guidance for using security contractors in contingency operations." 45

The Final Report criticizes the use of the inherently governmental rule as the trigger for deciding when outsourcing is appropriate in contingency operations. Even when functions are not inherently governmental, in some contexts, they may be inappropriate for outsourcing. ${ }^{46}$ In other words, just because something can be done does not mean it should be done. In contingency operations, it may not be appropriate to have contractors providing armed security protection for convoys because of the increased likelihood of either engaging the enemy or killing civilians. For example, the Department of State (DoS) hired private contractor, Blackwater, to perform armed security functions in which Blackwater ended up killing 17 civilians in Baghdad's Nisur Square. ${ }^{47}$ These Blackwater personnel actions had the same dire strategic ramifications for the U.S. Government as if Government personnel had killed the Iraqi civilians.

In addition, on numerous occasions, prohibited inherently governmental functions have been outsourced. ${ }^{48}$ Thus, instead, the decision to outsource should move toward a risk-based approach in which risk factors are analyzed to weigh contracting decisions. ${ }^{49}$ The Final Report lauded the Proposed (Draft) Letter's inclusion of risk-based considerations to be evaluated along with cost considerations in deciding whether to outsource critical functions. ${ }^{50}$ The Proposed (Draft) Letter took into account the concerns addressed in the Final Report. Regrettably, the risk-based considerations language used to evaluate outsourcing decisions was removed in the Final Policy Letter. ${ }^{51}$ 
To evaluate risk, the Final Report recommends assessing the "level of risk associated with contracting, and judging whether that level is or can be mitigated to an acceptable level." ${ }^{52}$ If levels of risk are too high, the work should stay or be brought in-house. The Final Report commends U.S. Army Field Manual (FM) 5-19, Composite Risk Management for providing a suitable analytical approach to assess risk that goes beyond a rote application of rules. The recommendation is to provide, across all agencies, risk-based guidance for choosing which type of personnel should perform specific functions. ${ }^{53}$ Especially stressed is the fact that risk considerations should trump cost-savings concerns. ${ }^{54}$ Such a statement is not incorporated in the Letter. To evaluate risk properly, acquisition experts are needed to deploy in Theater to assist in making outsourcing decisions and engage in effective contract administration and oversight.

\section{"Inattention to Contingency Contracting Leads to Massive Waste, Fraud, and Abuse." 55}

The Final Report stresses that the federal acquisition process was created to follow three fundamental tenets: (1) full and open competition so that all responsible firms are allowed to participate; (2) the process is transparent to provide public notice of the Government's requirements and awards; and, (3) the process has integrity and is enforced in accordance with federal laws and policies regarding "ethical behavior, timely audits, and contract oversight." ${ }^{56}$ In order to follow these tenets properly, acquisitions must be properly administered and managed to ensure the process is competitive, transparent, and has integrity.

A reduction in acquisition experts in OIF/OEF means there were inadequate numbers of contract acquisition personnel to properly administer and manage the contracts awarded. Thus, projects were not coordinated between foreign and domestic partners; contractor and subcontractor performance was left unmonitored, and cost-efficiency goals went unmet, which led to waste, fraud, and abuse. ${ }^{57}$

For example, according to the Fay Report, "contracting-related issues contributed to the problems at Abu Ghraib prison. Several of the alleged perpetrators of the abuse of detainees were employees of government contractors." ${ }^{58}$ First, for one of the contracts the Statement of Work, ${ }^{59}$ which describes the work to be performed on a contract, its location, performance standards, and special requirements - "made no mention of contractor employees actually conducting interrogations." ${ }^{60}$ Instead, the contract called for translation services only. ${ }^{61}$ This led to the civilian contractors neither being required to review nor sign the interrogation rules of engagement (IROE), which led to the contractors being improperly trained for interrogation - a massive contract administration failure. Plus, the contractors were working beyond the scope of the Statement of Work, which must be carefully drafted to avoid waste, fraud, and abuse.

In a second contract to provide interrogator services at Abu Ghraib prison, a contractor employee participated in drafting the Statement of Work prior to the contract being awarded to his employer. ${ }^{62}$ This type of conflict of interest could have been and should have been avoided with proper contract administration and management. 


\section{"Looming Sustainment Costs Risk Massive New Waste." 63}

Recommendation:

- "Take actions to mitigate the threat of additional waste from unsustainability." 63a

Projects underway in Iraq and Afghanistan may not be sustainable after the U.S. presence leaves the Theater. ${ }^{64}$ Because projects may not have been properly scaled or implemented, they may be unaffordable after the U.S. departure or the projects themselves may have distorted the local market, creating inflation problems in the region. ${ }^{65}$ Thus, long-term projects or services that are to be turned over to the host nation should be evaluated in terms of long-term costs and sustainability and associated risks. ${ }^{66}$ For example, Afghanistan's current economic situation makes the country unlikely to be able to sustain enduring costs to maintain roads, hospitals, power plants, training centers, irrigation projects, etc., that the United States has already spent billions of dollars to build. ${ }^{67}$

\section{"Agencies Have Not Institutionalized Acquisition as a Core Function."}

\section{Recommendations:}

- "Elevate positions and expand the authority of civilian officials responsible for contingency contracting at the Department of Defense (DoD) and DoS, and the U.S. Agency for International Development (USAID)." ${ }^{67 b}$

- "Elevate and expand the authority of military officials responsible for contingency contracting on the Joint Staff, the combatant commanders' staffs, and in the military Services." 67c

A culture change is needed in order to institutionalize acquisition as an agency core function. First, agencies need to admit that contractors are an integral and essential part of the workforce for contingency operations. Thus, acquisition experts need to permeate through the planning and training aspects of the agency. Currently, "[s]ervices contracting is not seen as an attractive career for advancement to senior levels" in DoD. ${ }^{68}$ This is in contrast to weapons systems contracting, but services contracts account for 66 percent of the total contract awards in OIF/OEF since 2010. ${ }^{69}$ Until there is a culture change so that services contracting is seen as a viable career option, the best and the brightest may choose to gravitate somewhere else, and DoD and the Services will fail to invest in service contracting infrastructure and core competencies.

The Final Report observes that the 2010 Quadrennial Defense Review noted a 10 percent decline in acquisition professionals over the previous decade. ${ }^{70}$ As mentioned previously, the Final Report specifically recommends that contracting should become a separate directorate, J10, in the Joint Staff, instead of taking a subordinate role in combatant command logistics (J4) directorate. ${ }^{71}$ Thus, a general/flag officer would lead this directorate and could more easily coordinate and share information with other Joint Staff directorate leaders. The Joint Staff, however, disagrees with this recommendation, as it is unfeasible, given the current effort to reduce the number of flag officers and not add new structure to the Joint Staff. ${ }^{72}$ Without creating a new directorate, operational 
contracting efforts will be vulnerable to budget cuts again and to the loss of acquisition personnel in key areas. Also, without elevating positions and creating career advancement for personnel, expertise will not be developed in acquisition management. Those promoted to high positions to run acquisitions generally will not have experience in these areas prior to their appointment.

Having acquisition as subordinate to the J4 directorate perpetuates the problems and "reflects outdated thinking that contracting is only a method to achieve logistical support - not a full spectrum of operational contract support." ${ }^{13}$ Consequently, those officers who achieve general/flag officer rank lack contracting experience and the understanding of the "broad range of roles contractors play in supporting military operations." ${ }^{74}$ Elevating to a separate acquisition directorate from the J4 directorate could facilitate the type of contracting that gets done in contingency operations. ${ }^{75}$

Without contracting becoming its own J10 directorate, acquisition as it is addressed in planning will suffer. Joint planning is undertaken utilizing, inter alia, the Joint Operations Planning Process, Operational Design, and Joint Strategic Capabilities Planning. The coordination and agency structures are established through the Joint Staff directorates. Without having a champion outside of the J4 Logistics directorate, the way contracting is evaluated during planning in contingency operations is unlikely to change because the culture and ethos of the Services will remain unchanged.

\section{"Agency Structures and Authorities Prevent Effective Interagency Coordination."76}

\section{Recommendations:}

- "Establish a new, dual-hatted senior position at the Office of Management and Budget and the NationalSecurity Council staff to provide oversight and strategic direction." 77

- "Create a permanent office of inspector general for contingency operations."

In contingency and stability operations, DoD, DoS, and USAID must work together to accomplish national strategic objectives in the conflict zone. Each agency has a different mission with a different organizational structure. The interagency process should work to bolster the ability to coordinate across agencies as opposed to hampering the process. ${ }^{79}$ Unfortunately, each agency is often unclear about where the jurisdiction of one agency ends and the other begins. The talents brought to bear should be complementary and not redundant. The coordination processes are currently too complex to function effectively ${ }^{80}$ They would probably work more effectively if there were a Joint Staff directorate for contracting, in which the interagency coordination efforts are structurally integrated into the joint planning processes.

\section{“Contract Competition, Management, and Enforcement Are Ineffective."}

\section{Recommendations.}

- "Set and meet annual increases in competition goals for contingency contracts." 82

- "Improve contractor performance-data recording and use. [and]

- Strengthen enforcement tools." ${ }^{83}$ 
- "Provide adequate staffing and resources, and establish procedures to protect the government's interests." ${ }^{84}$

The last recommendation focuses primarily on ensuring cost considerations and competition are injected into the process to avoid rampant single-award-task and-delivery order contracts that effectively inject monopolistic-type pricing. Particularly egregious have been practices that favor the incumbent in following procurements. ${ }^{85}$

Interestingly, a little known fact is that the "military relied upon the Department of the Interior's National Business Center (DOI's NBC) to procure contractor personnel to conduct interrogations in Iraq and Guantanamo Bay." 86 This became possible because the Army was allowed, in accordance with various statutes, ${ }^{87}$ to hand off its procurement function to the DOI's NBC, which received a fee for awarding contracts for the Army ${ }^{88}$ This fee-based process creates an ill-advised incentive for agencies to pursue fees rather than practice good contract administration. As a result, agencies are encouraged to award a lot of contracts without the commensurate incentive to manage them well. The Inspector General for the DOI found "inherent conflict in a fee-for-service operation, where procurement personnel in their eagerness to enhance organization revenues have found shortcuts to Federal procurement procedures and procured services for clients whose own agencies might not do so." ${ }^{89}$

Full and open competition, transparency, and procurement process integrity - the fundamental tenets of the federal procurement system - can be realized only when sufficient numbers of professional experts in procurement award, administer, and manage acquisitions. The laws, policies, and regulations presume agencies rely upon warranted purchasing professionals to award and manage agency procurement. ${ }^{90}$ When there is a shortage of qualified personnel to carry out these duties, the environment is ripe for waste, fraud, and abuse.

In particular, in OIF/OEF, there was over-reliance on single-award task-and-delivery order contracts, otherwise known as requirements contracts or indefinite delivery/ indefinite quantity (ID/IQ) contracts. ${ }^{91}$ These types of contracts are open-ended and do not specify a definite amount of goods (deliveries) or services (tasks) the Government will need in the future. ID/IQ contracts are very flexible and allow the Government, as the need arises, to place orders without creating a new contract for each transaction. If, however, ID/IQ contracts are not administered well, they can easily be mismanaged. ${ }^{92}$ Importantly, the Statement of Work can be written too broadly or improperly, which leads to waste, fraud, and abuse. The contracts for interrogator services at Abu Ghraib prison were ID/IQ contracts. The use of ID/IQ contracts, in and of itself, is not necessarily the problem. These contracts are efficient and streamline the procurement process. Because of this, they are unlikely to be reduced in use. The problem lies, however, in the improper management of ID/IQ contracts, which can lead to waste, fraud, and abuse.

\section{“The Way Forward Demands Major Reforms."}

\section{Recommendations.}

- "Congress should provide or reallocate resources for contingency-contracting reform to cure or mitigate numerous defects described by the Commission." ${ }^{94}$ 
- "Congress should enact legislation requiring regular assessment and reporting of agencies' progress in implementing reform recommendations." ${ }^{95}$

In order for the Final Report recommendations to be realized, Congress must act to provide the commensurate resources, but DoD and the Department of the Army have to change their cultures to embrace contracting as a core competency, recognized as part of warfighting.

It is important to note that outsourcing is not just about ceding sovereignty and allowing contractors to step in for the Government. ${ }^{96}$ Outsourcing can also be an enabler for politicians to amass power and work around the regulations and laws in place to keep politicians accountable to the people. ${ }^{97}$ This allows the Government to do things it could not otherwise do through private proxies, like circumventing privacy laws or other regulations or public policy discussions. ${ }^{98}$ These problems have been conflated, while only the former is being addressed through regulation and policy ${ }^{99}$ For example, Chapter 8 of the Final Report notes specifically that the acquisition community "had no seat at the table in deciding whether to use contractors, and no voice in budgetary debates on how big the federal acquisition workforce should be to manage the hundreds of billions of dollars in contracts for which it was responsible." ${ }^{100}$ However, the entire chapter focuses more on the waste, fraud, and abuse problem and not on the decision to outsource a function.

\section{OVERVIEW OF THE OFPP POLICY LETTER 11-01 (DEFINITIONS, TESTS, AND EXAMPLES)}

The purpose of OFPP Policy Letter 11-01 (Letter) ${ }^{101}$ is to "clarify when governmental outsourcing for services is and is not appropriate."102 The Letter sets forth that when Government agency action is employed it should be taken as the result of "informed, independent judgments made by [G]overnment officials." ${ }^{103}$ The idea is that this will ensure good governance such that the actions taken are accountable to the public through individuals who are bound by laws controlling their conduct and ensure the proper use of congressionally appropriated funds. Generally, the Letter accomplishes this by prohibiting contractors from performing inherently governmental functions, which now has a single definition: ${ }^{104}$ "one that is so intimately related to the public interest as to require performance by Federal Government employees." ${ }^{105}$ In Appendices A, B, and C, the Letter gives examples of inherently governmental functions as well as examples of what are not normally considered inherently governmental functions. ${ }^{106}$

Although contractors may perform work that is "closely associated with inherently governmental functions," special consideration is to be given to federal employees. Contractors may also perform "critical functions," 107 but as with "closely associated inherently governmental functions," the Letter states that there is increased federal employee oversight over contractors performing such work so that the public interest is protected through competent federal employee contract management. ${ }^{108}$ Pervasive throughout the Letter is language regarding federal agencies that have an adequate number of personnel, who have the technical skills and expertise to administer contracts to protect the public interest and maintain control of the agency mission and operations. ${ }^{109}$ In fact, there is a section called "Strategic Human Capital Planning," which suggests agencies 
build competencies in contract administration and "identify strategies and goals for addressing both the size and capability of the acquisition workforce."110

The Letter sets forth guidelines to identify inherently governmental functions. First, Appendix A contains a list of illustrative inherently governmental functions. ${ }^{111}$ If a function is not on that list, the Letter provides two tests for identifying whether a function is inherently governmental: "the nature of the function" test and the "exercise of discretion" test. ${ }^{112}$ The former assesses whether the function involves exercising U.S. sovereign powers such that the function is uniquely governmental regardless of the type or level of discretion. ${ }^{113}$ For the latter, "a function requiring the exercise of discretion is inherently governmental if the exercise of that discretion commits the government to a course of action" when there is an alternative and it is not otherwise limited by existing policy, procedures, or orders. ${ }^{114}$ Here, contractors may perform functions in which the contractor does not decide on the overall course of action, but is tasked to develop options. The key is that contractors are not to supplant or preempt a government official's discretion or authority. ${ }^{115}$

Appendix B lists examples of functions "closely associated with the performance of inherently governmental functions." 116 If it is economically efficient and deemed appropriate for a contractor to undertake such a function, Appendix C sets forth responsibilities for agency oversight in administering such contracts. ${ }^{117}$

Determining whether a function is critical is covered in 5-1(a)(2)(b) of the Letter. This section lists examples of critical functions and requires agencies to have an adequate number of positions filled by federal employees who have internal expertise and can manage and oversee contractors in order to accomplish the agency mission. ${ }^{118}$ Section 5-2 of the Letter sets forth agency management responsibilities before the contract is awarded (pre-award) to document that the services being procured are consistent with the Letter policies and guidelines. ${ }^{119}$

\section{EVALUATING THE OFPP POLICY LETTER 11-01 REQUIREMENTS}

The Letter's primary focus links the definition of inherently governmental function with what should and should not be outsourced. The Letter prohibits contractors from performing inherently governmental functions and states that substantial Government employee oversight is needed over contractors performing closely associated inherently governmental functions and critical functions so that the public interest is protected through competent federal employee contract management. This is a great idea, but currently there are not enough acquisition personnel throughout all levels of government to take on such oversight. The Letter indirectly recognizes this problem in specifically addressing the need for strategic agency human capital plans to increase and improve the acquisition workforce, but without congressional funding for new positions and training, this cannot be realized.

The Letter utilizes lists in the appendices to give specific examples of what functions would be considered inherently governmental. The word, "[c]ombat" is listed. Depending on how "combat" is interpreted, there are already many inherently governmental functions being practiced by contractors, even though this is specifically prohibited in the list. Such practices are happening because there is not enough organic talent 
within the Government to perform the tasks required to do the Government's work. ${ }^{120}$ Thus, it may not be fully possible to implement the Letter's requirements until agency core competence is increased and improved, which will require significant funding from Congress. In any case, the key is that the Government agency should be able to accomplish its mission whether a contractor is performing the task or not. If contracts were administered more effectively, the problems that occurred in OIF/OEF could have been reduced.

When work is not specifically reserved for federal employees, the Letter provides that cost-effective and technical considerations should inform the outsourcing decision. ${ }^{121}$ Risk-based considerations, which would determine whether it is too risky to outsource a function irrespective of cost considerations, are not included in the final version of the Letter. The initial Draft Letter included such risk-based factors. ${ }^{122}$ The Letter does not follow the Final Report's recommendation to provide, across all agencies, risk-based guidance for choosing what type of personnel should perform specific functions. ${ }^{123}$

It is important to remember that outsourcing can be used as a workaround to avoid complying with laws and regulations that are in place to keep the Government accountable for decisions made. ${ }^{124}$ For example, during OIF there were not enough troops to win the peace in Iraq, so contractors were needed in great numbers for stability operations; these contractors allowed DoD to keep troop levels down. Because this was considered emergency funding, the transparent normal budget process was avoided and the opaque supplemental funding mechanisms were used. ${ }^{125}$ The Letter looks at definitions like inherently governmental as the primary way to make an outsourcing determination without looking at whether an agency is seeking a workaround to circumvent political processes and engaging in something the Government should not be doing, unconstitutional data collection, for example. ${ }^{126}$

What is in the Letter, alone, will not be sufficient to correct the significant contract administration problems that occurred in OIF/OEF. Without a change in culture at the agency level and establishing government contracting as a core competence, the errors are likely to persist.

\section{CONCLUSION}

In its Final Report, the Commission made findings and recommendations to prevent the acquisition mistakes made in OIF/OEF from recurring. The Office of Procurement Policy provided guidance through its Letter, which takes some initial steps toward improving the Government's procurement process. Fundamentally, contract administration failures in procurement created a lot of the waste, fraud, and abuse in OIF/OEF. To fix this problem structurally, the number and technical competence of Government contracting experts focused on contract administration must increase. Even though the Letter alludes to these increases, only congressional funding can authorize adding positions and creating solid career paths for such experts.

Further, the U.S. military needs to change its culture and make Government contracting a core competence for its personnel, civilian and military. An effective way to change a culture is to add a contracting directorate as a Joint Staff function as the Commission 
recommended. Removing government contracting from its subordinate role in the logistics directorate, J4, will effectively integrate acquisition into the joint planning process. This will help interagency coordination of contract administration as well as provide career opportunities for acquisition experts to move up and advance. However, adding a new contracting directorate during this age of fiscal austerity is probably unlikely.

Full and open competition, transparency, and procurement process integrity are fundamental tenets of Government contracting. Proper contract administration can ensure these tenets are vigorously pursued. Research in the future should probably look more carefully at an agency's initial decision to outsource. It is important to safeguard against policymakers deciding to outsource with the intention of circumventing the political process. Not only the true size of Government, but the real cost of war, including contractor casualties, should be transparent to the public.

\section{ENDNOTES}

1. Commission on Wartime Contracting in Iraq and Afghanistan, Transforming Wartime Contracting: Controlling Costs, Reducing Risks, Final Report to Congress, August 2011, pp. 2-3 (hereafter: Final Report), available from www.wartimecontracting.gov, accessed May 12, 2014.

2. Peter W. Singer, "Warriors for Hire in Iraq," April 15, 2004, Salon.com, available from www.salon. com/2004/0415/warriors, accessed May 12, 2014.

3. National Defense Authorization Act, Sec. 841, Public Law 181, 110th Cong., 1st Sess., January 28, 2008, pp. 230-234.

4. Office of Management and Budget, Office of Federal Procurement Policy (OFPP), Publication of the Office of Federal Procurement Policy (OFPP) Letter 11-01, Performance of Inherently Governmental and Critical Functions (hereafter: Letter), 76 Fed. Reg. 56,236, September 12, 2011.

5. Final Report, pp. 43-44.

6. Office of Management and Budget, OFPP, Proposed Policy Letter, Work Reserved for Performance by Federal Government Employees (Draft Letter), March 2010, available from www.whitehouse.gov/omb/ procurement_work_performance, accessed May 12, 2014.

7. Office of Management and Budget, OFPP Policy Letter 11-01, Performance of Inherently Governmental and Critical Functions, Federal Register Vol. 76, No. 176, Washington, DC: Office of Management and Budget, September 12, 2011, 56237 ("Agencies' annual Human Capital Plan for Acquisition shall identify specific strategies and goals for addressing both the size and capability of the acquisition workforce, including program managers and contracting officer representatives").

8. Final Report, pp. 114-115.

9. Ibid., p. 115.

10. U.S. Joint Chiefs of Staff, Joint Task Force Headquarters, Joint Publication 3-33, Washington, DC: U.S. Joint Chiefs of Staff, July 20, 2012, p. I-4-I-7.

11. Final Report, pp. 116, 121. 
12. Paul C. Light, The True Size of Government, Washington, DC: The Brookings Institution Press, 1999, pp. 46-48.

13. Steven L. Schooner and Collin D. Swan, "Suing the Government as a 'Joint Employer' - Evolving Pathologies of the Blended Workforce," Government Contractor, Vol. 52, No. 39, October 20, 2010, p. 341.

14. Paul C. Light, "Fact Sheet on the New True Size of Government," Washington, DC: The Brookings Institution, September 5, 2003, available from www.brookings.edu/research/articles/2003/09/05politics-light, accessed April 4, 2014.

15. Steven L. Schooner and Daniel S. Greenspahn, “Too Dependent on Contractors? Minimum Standards for Responsible Governance," Journal of Contract Management, Vol. 8, September 25, 2008, p. 10.

16. Report of the Acquisition Advisory Panel to the Office of Federal Procurement Policy and the United States Congress (hereafter: Advisory Panel), Chap. 6, "Appropriate Role of Contractors Supporting Government," p. 392, available from www.acquisition.gov/comp/aap/documents/Chapter6.pdf, accessed May 6, 2014.

17. Paul C. Light, "Outsourcing and the True Size of Government," 33 Pub. Cont. L.J., Winter 2004, pp. 311, 312.

18. Light, True Size, p. 7.

19. Statement of Steven L. Schooner before the United States Senate Democratic Policy Committee, “Iraq Contracting: Predictable Lessons Learned," 108th Cong., September 10, 2004, citing 48 C.F.R. § 37.104(a).

20. Ibid., p. 19.

21. Schooner and Greenspahn, p. 16.

22. Ibid., p. 10.

23. Major General George R. Fay, Army Regulation 15-6, Investigation of the Abu Ghraib Detention Facility and the 205th Military Intelligence Brigade (hereafter: Fay Report), 2004, available from news.findlaw.com/ hdocs/docs/dod/fay82504rpt.pdf, accessed May 10, 2014.

24. Ibid., p. 51 (listing contractor personnel supervisors with military subordinates).

25. Letter, 76 Fed. Reg. 56,237; Final Report, pp. 2-4.

26. Fay Report, p. 49.

27. William C. Moorhouse, "Expediency at the Expense of Governmental Propriety: Personal Service Contractors in the Procurement Office," Public Contract Law Journal, Vol. 41, Summer 2012, p. 3.

28. Report of the Acquisition Advisory Panel to the Office of Federal Procurement Policy and the United States Congress, Chap. 6: "Appropriate Role of Contractors Supporting Government," pp. 410411, available from www.acquisition.gov/comp/aap/documents/Chapter6.pdf, accessed May 6, 2014; Moorhouse, "Expediency," p. 3.

29. U.S. Congress, Senate, Committee on Appropriations, The President's FY 2008 Supplement Request for the Wars in Iraq and Afghanistan, 110th Cong., September 26, 2007.

30. National Defense Authorization Act of 2008, Sec. 841, 110th Cong., 1st Sess., Report 110-477, January 28, 2008. 
31. Commission on Wartime Contracting in Iraq and Afghanistan, Transforming Wartime Contracting: Controlling Costs, Reducing Risks, Final Report to Congress, August 2011, available from www.wartimecontracting.gov, accessed April 15, 2014.

32. Final Report, p. 68, "The Commission examined authoritative evidence on waste and fraud. It estimates that wartime-contracting waste in Iraq and Afghanistan ranges from 10 percent to 20 percent of the \$206 billion spent since fiscal year (FY) 2002, projected through the end of FY 2011. The Commission also estimates that fraud during the same period ran between 5 and 9 percent of the \$206 billion."

33. Final Report, pp. 16-35.

34. Ibid., pp. 16-17.

35. Ibid.

36. Ibid., p. 19.

37. Ibid., pp. 2, 19.

38. Ibid., p. 30.

39. Ibid., p. 32.

40. Ibid.

41. Ibid., pp. 38-64.

42. Ibid., pp. 49-52.

43. Ibid., pp. 52-61.

44. Ibid., pp. 61-63.

45. Ibid., p. 64.

46. Ibid., pp. 39-40.

47. Ibid., p. 30. Matt Apuzzo, “Trying to Salvage Remains of Blackwater Cases," May 11, 2014, available from www.nytimes.com/2014/05/12/us/trying-to-salvage-remains-of-blackwater-case.html?ref=todayspaper, accessed May 12, 2014.

48. Ibid., p. 40.

49. Ibid., pp. $43-44$.

50. Ibid.

51. Fed. Reg. 76, 56,239, 5-2(b)(2). Draft Letter, 5-2b(b)(2)(ii) reads, in pertinent part:

If an agency has sufficient internal capability to control its mission and operations, the extent to which additional work is performed by federal employees should be based on cost considerations 'unless performance and risk considerations in favor of federal employee performance will clearly outweigh cost considerations'

(emphasis added where language was removed from Final Letter). 
52. Final Report, p. 44.

53. Ibid., p. 45.

54. Ibid.

55. Ibid., pp. 68-94.

56. Ibid., p. 150.

57. Ibid., pp. 150-151.

58. Fay Report, pp. 47-48.

59. FAR § 8.405-2(b) in pertinent part, reads: Statement of Work: All Statements of Work shall include a description of the work to be performed; location of work; period of performance; deliverable schedule; applicable performance standards; and any special requirements (e.g. security clearances, travel, special knowledge)...

60. Fay Report, p. 48.

61. Ibid.

62. Ibid., p. 49.

63. Final Report, pp. 98-111.

63a. Ibid., p. 111.

64. Ibid., p. 98.

65. Ibid., p. 99.

66. Ibid., p. 111.

67. Ibid., p. 98.

67a. Ibid., p. 114.

67b. Ibid., p. 128.

67c. Ibid., p. 129.

68. Ibid., p. 117.

69. Ibid.

70. The 2014 Quadrennial Defense Review discusses acquisition in terms of "Better Buying Power and Financial Reforms." Highlighted is to, "Improve tradecraft in acquisition of contracted services... and the professionalism of the total acquisition workforce." Chuck Hagel, Quadrennial Defense Review, Washington, DC: U.S. Department of Defense, March 4, 2014, pp. 46-47.

71. Final Report, pp. 115, 119.

72. Ibid., p. 120. 
73. Ibid., p. 119.

74. Ibid., pp. 119-120.

75. There are no current plans to create a contracting directorate within the Joint Staff. Joint Publication 4-0 was amended in October 2013, and contracting remains in a subordinate role to the J4 Logistics directorate.

76. Final Report, pp. 132-147.

77. Ibid., pp. 144-147.

78. Ibid., p. 147.

79. Ibid., p. 136.

80. Ibid., pp. 141-142.

81. Ibid., pp. 150-163.

82. Ibid., pp. 155-156.

83. Ibid., pp. 156-160.

84. Ibid., pp. 160-163.

85. Ibid., p. 152.

86. Steven L. Schooner, "Contractor Atrocities at Abu Ghraib: Compromised Accountability in a Streamlined, Outsourced Government," Stanford Law and Policy Review, Vol. 16, 2005, pp. 549, 564, citing Memorandum from Earl Devaney, Inspector General, Department of the Interior, to Assistant Secretary for Policy, Management \& Budget, July 16, 2004, (hereafter: Interior IG Report), available from www. gpo.gov/fdsys/pkg/GPO-DOI-IGREPORTS-2004-i-0049/pdf/GPO-DOI-IGREPORTS-2004-i-0049.pdf, accessed May 9, 2014.

87. Clinger-Cohen Act, 40 U.S.C. § 1412(e), 2005; The Economy Act, 31 U.S.C. §§ 1535-1536, 2005 (enacted to reduce redundancy among federal agency activities).

88. Schooner, "Contractor Atrocities," pp. 564-572 (providing an extensive discussion on fee-based acquisition instruments).

89. Interior IG Report.

90. Federal Acquisition Regulation Subpart 1.6, 48 Code of Federal Regulations 1.16, reads in pertinent part:

Contracting officers are responsible for ensuring performance of all necessary actions for effective contracting, ensuring compliance with the terms of the contract, and safeguarding the interests of the United States in its contractual relationships. In order to perform these responsibilities, contracting officers should be allowed wide latitude to exercise business judgment. Contracting officers shall-

(a) Ensure that the requirements of 1.602-1(b) have been met, and that sufficient funds are available for obligation;

(b) Ensure that contractors receive impartial, fair, and equitable treatment;

(c) Request and consider the advice of specialists in audit, law, engineering, information security, transportation, and other fields, as appropriate; and, 
(d) Designate and authorize, in writing and in accordance with agency procedures, a contracting officer's representative (COR) on all contracts and orders other than those that are firm-fixed price, and for firm-fixed-price contracts and orders as appropriate, unless the contracting officer retains and executes the COR duties. See 7.104(e). A COR-

(1) Shall be a Government employee, unless otherwise authorized in agency regulations;

(2) Shall be certified and maintain certification in accordance with the current Office of Management and Budget memorandum on the Federal Acquisition Certification for Contracting Officer Representatives (FAC-COR) guidance, or for DoD, in accordance with the current applicable DoD policy guidance;

(3) Shall be qualified by training and experience commensurate with the responsibilities to be delegated in accordance with agency procedures;

(4) May not be delegated responsibility to perform functions that have been delegated under 42.202 to a contract administration office, but may be assigned some duties at 42.302 by the contracting officer;

(5) Has no authority to make any commitments or changes that affect price, quality, quantity, delivery, or other terms and conditions of the contract nor in any way direct the contractor or its subcontractors to operate in conflict with the contract terms and conditions;

(6) Shall be nominated either by the requiring activity or in accordance with agency procedures; and,

(7) Shall be designated in writing, with copies furnished to the contractor and the contract administration office:

(i) Specifying the extent of the COR's authority to act on behalf of the contracting officer;

(ii) Identifying the limitations on the COR's authority;

(iii) Specifying the period covered by the designation;

(iv) Stating the authority is not redelegable; and

(v) Stating that the COR may be personally liable for unauthorized acts.

48 C.F.R. § 1.602-2 Responsibilities.

91. Final Report, p. 150. For a description of ID/IQ contracts, see FAR § 16.5.

92. Schooner, "Contractor Atrocities," pp. 564-565.

93. Final Report, pp. 166-172.

94. Ibid., pp. 168-171.

95. Ibid., pp. 171-172.

96. Paul R. Verkuil, Outsourcing Sovereignty: Why Privatization of Government Functions Threatens Democracy and What We Can Do About It, New York: Cambridge University Press, 2007; Allison Stanger, One Nation Under Contract: The Outsourcing of American Power and the Future of Foreign Policy, New Haven, CT: Yale University Press, 2009.

97. Jon D. Michaels, "Privatization's Pretensions," University of Chicago Law Review, Vol. 77, Spring 2010, p. 723.

98. Ibid.

99. Ibid., p. 767.

100. Final Report, p. 166.

101. Letter, Fed. Reg. 76, 56, p. 227.

102. Ibid. 
103. Ibid., pp. 56, 236.

104. Prior to the Letter, agencies had to contend with differing definitions of inherently governmental function in the Federal Acquisitions Regulation (FAR) subpart 7.5 and OMB Circular A-76.

105. Letter, Fed. Reg. 76, 56,236. OFPP selected the Federal Activities Inventory Reform Act definition of inherently governmental. Public law 105-270.

106. Ibid., 56,240-56,242.

107. Critical function is defined as "a function that is necessary to the agency being able to effectively perform and maintain control of its mission and operations."

108. Letter, Fed. Reg. 76, 56,236.

109. Ibid., 56,236-56,240.

110. Ibid., 56,237.

111. Ibid., 56,240-56,241.

112. Ibid., 56,237.

113. Ibid., Section 5-1(a)(1)(i).

114. Ibid., Section 5-1(a)(1)(ii)(A).

115. Ibid., 56,238, Section 5-1(a)(1)(ii)(C).

116. Ibid., 56,241.

117. Ibid., 56,241-56,242.

118. Ibid., 26,238.

119. Ibid., 56,238-56,239.

120. Acquisition Advisory, p. 391. Government Contractors: Are Service Contractors Performing Inherently Governmental Functions? Report to the Chairman, Federal Service, Post Office and Civil Service Subcommittee on Governmental Affairs, U.S. Senate, GAO/GGD-92-11, Washington, DC: U.S. Government Accountability Office, November 1991, p. 6.

121. Letter, Fed. Reg. 76, 56,236 ("Nothing in this guidance is intended to discourage the appropriate use of contractors. Contractors can provide expertise, innovation, and cost-effective support to Federal agencies for a wide range of services").

122. Office of Federal Procurement Policy (OFPP) Proposed Policy Letter, Work Reserved for Performance by Federal Government Employees, Washington, DC: Office of Management and Budget, March 2010, available from www.whitehouse.gov/omb/procurement_work_performance, accessed May 11, 2014.

Finally, if an agency determines that it has sufficient internal capability to control its mission and operations, the proposed policy would require the consideration of cost to establish the extent to which additional critical work is performed by federal employees, unless performance and risk considerations in favor of federal employee performance would clearly outweigh cost considerations. 
123. Final Report, p. 50.

124. Moorhouse, “Expediency," p. 3.

125. Final Report, p. 39.

126. Michaels, “Privatization's Pretensions," p. 766. 


\title{
U.S. ARMY WAR COLLEGE
}

\author{
Major General William E. Rapp \\ Commandant
}

\author{
*****
STRATEGIC STUDIES INSTITUTE
and \\ U.S. ARMY WAR COLLEGE PRESS \\ Director \\ Professor Douglas C. Lovelace, Jr. \\ Director of Research \\ Dr. Steven K. Metz
}

\author{
Author \\ Lieutenant Colonel Katherine E. White, USAR \\ Editor for Production \\ Dr. James G. Pierce \\ Publications Assistant \\ Ms. Rita A. Rummel \\ ***** \\ Composition \\ Mrs. Jennifer E. Nevil
}




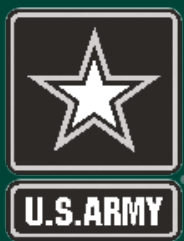

THE

UNITED STATES

ARMY WAR COLLEGE

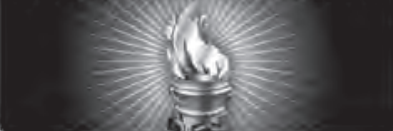

STRENGTH

FOR THIS AND OTHER PUBLICATIONS, VISIT US AT

http://www.carlisle.army.mil/

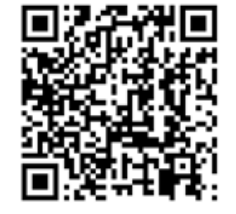

This Publication

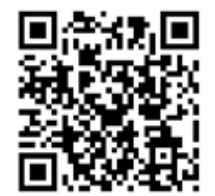

SSI Wehsite

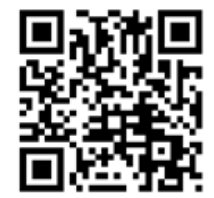

usaWc Website 